\title{
Mutasi Gen NPHS2 (412C $\rightarrow$ T, 419delG) dan Manifestasi Klinis Sindrom Nefrotik Resisten Steroid Anak Indonesia
}

\author{
Dedi Rachmadi, Dany Hilmanto, Ponpon Idjradinata, Abdurahman Sukadi \\ Departemen Ilmu Kesehatan Anak Fakultas Kedokteran Universitas Padjadjaran \\ Rumah Sakit Dr. Hasan Sadikin Bandung
}

\begin{abstract}
Abstrak
Sindrom nefrotik resisten steroid (SNRS) karena mutasi gen nephrotic syndrome type 2 (NPHS2) mempunyai manifestasi klinis lebih berat dibandingkan dengan SNRS tanpa mutasi gen. Penelitian ini bertujuan untuk mengetahui mutasi gen $N P H S 2(412 C \rightarrow T, 419$ delG $)$ pada SNRS anak Indonesia dan melihat perbedaan manifestasi klinisnya. Penelitian ini berupa observasional potong silang pada 88 penderita SNRS yang diambil secara consecutive admission dari 10 rumah sakit pendidikan di Indonesia, periode September 2006-Desember 2007. Analisis mutasi $412 C \rightarrow T$ dan 419 del $G$ diperiksa dengan polymerase chain reaction. Analisis statistik menggunakan multivariat dan uji chi-square. Dari 88 SNRS didapat $58(66 \%)$ mutasi $412 C \rightarrow T$ dan $69(78 \%)$ mutasi $419 \mathrm{delG}$. Hasil analisis multivariat variabel interval manifestasi klinis (tekanan darah sistol dan diastol, kadar kreatinin serum, usia serangan pertama, dan pertumbuhan) antara kelompok mutasi gen $412 \mathrm{C} \rightarrow T$, 419delG dan kelompok tanpa mutasi gen didapatkan masing-masing $\mathrm{F}=0,316 ; \mathrm{p}=0,902$ dan $\mathrm{F}=0,651 ; \mathrm{p}=0,662$. Hasil analisis univariat dari variabel nominal manifestasi klinis sebagai berikut: hematuria, $p=0,231(0,726)$; hipertensi, $\mathrm{p}=0,286(0,741)$; usia serangan pertama, $\mathrm{p}=0,372(0,304)$; pertumbuhan skor $Z, p=0,087(0,595)$, dan kreatinin serum $\mathrm{p}=0,049(0,080)$. Tidak terdapat perbedaan manifestasi klinis antara penderita SNRS dengan mutasi gen NPHS2 $(412 C \rightarrow T, 419$ del $G)$ dan penderita SNRS tanpa mutasi gen, kecuali kadar kreatinin serum pada penderita SNRS dengan mutasi gen $412 C \rightarrow T$. [MKB. 2011;43(4):193-8].
\end{abstract}

Kata kunci: Manifestasi klinis, mutasi gen $N P H S 2(412 C \rightarrow T, 419 \mathrm{delG})$, sindrom nefrotik resisten steroid

\section{NPHS2 (412 $\mathrm{C} \rightarrow \mathrm{T}$ and 419delG) Gene Mutation and Their Clinical Manifestation in Indonesian Steroid-Resistant Nephrotic Syndrome}

\begin{abstract}
Steroid resistant nephrotic syndrome (SRNS) due to nephrotic syndrome type 2 (NPHS2) gene mutation has more severe clinical manifestation than those without mutation. This study was designed to find NPHS gene mutation in $412 \mathrm{C} \rightarrow \mathrm{T}$ and $419 \mathrm{delG}$ in Indonesian SRNS and to see differences in clinical manifestation. The observational cross sectional study was performed on 88 SRNS. Subjects were taken consecutively from 10 teaching hospitals in Indonesia during September 2006 to December 2007. Analysis for $412 \mathrm{C} \rightarrow \mathrm{T}$ and 419delG mutations were examined by polymerase chain reaction. Multivariate and chi-square-test analysis were used. Of 88 SNRS, $58(66 \%)$ with $412 \mathrm{C} \rightarrow \mathrm{T}$ and $69(78 \%)$ with $419 \mathrm{delG}$ mutations. Multivariate analyses for interval variable of clinical manifestations (systolic and diastolic blood pressure, serum creatinin level, age of onset and growth) between SRNS with NPHS2 412C $\rightarrow$ T, 419delG mutation and SRNS without mutation were $F=0.316, p=0.902$ and $\mathrm{F}=0.651, \mathrm{p}=0.662$, respectively. While univariate analyses for nominal variable of clinical manifestation were as follow: hematuria, $p=0.231(0.726)$; hypertension, $p=0.286(0.741)$; age of onset, $p=0.372(0.304)$; Z-score growth, $\mathrm{p}=0.087(0.595)$ and serum creatinin, $\mathrm{p}=0.049(0.08)$. There is no difference of clinical manifestation between SRNS with NPHS2 $412 \mathrm{C} \rightarrow \mathrm{T}$, 419delG mutation and SRNS without mutation, except on serum creatinin in $412 \mathrm{C} \rightarrow \mathrm{T}$ mutation. [MKB. 2011;43(4):193-8].
\end{abstract}

Key words: Clinical manifestation, NPHS2 (412C $\rightarrow$ T, 419delG) gene mutation, steroid resistant nephrotic syndrome

Korespondensi: Dr. Dedi Rachmadi, dr., Sp.A(K)., M.Kes, Departemen Ilmu Kesehatan Anak Fakultas Kedokteran Universitas Padjadjaran-RS Dr. Hasan Sadikin Bandung, jalan Pasteur 38 Bandung, telepon (022) 2035957/(022) 2034426, mobile081320608455, e-mail dedirachmadi@yahoo.com 


\section{Pendahuluan}

Dalam beberapa tahun terahir ini telah berkembang pesat penelitian genetik molekuler, termasuk ditemukannya beberapa gen yang terlibat dalam patogenesis sindrom nefrotik, yaitu gen yang mengkode sintesis protein yang berperan dalam mempertahankan struktur celah diafragma/ membran filtrasi glomerulus. Gen nephrotic syndrome type 2 (NPHS2) mengkode sintesis protein podosin, terletak pada kromosom 1q25-31, mutasi pada gen NPHS2 ditemukan $20-30 \%$ pada sindrom nefrotik resisten steroid (SNRS). ${ }^{1-3}$

Diagnosis SNRS dengan analisis mutasi gen sangat penting karena jenis mutasi dapat menggambarkan berat-ringannya manifestasi klinis/ fenotipe. ${ }^{3,4}$ Pemeriksaan gen NPHS2 pada semua ekson (8 ekson) penderita SNRS dengan sekuensing, mendapatkan mutasi paling banyak pada ekson $3,{ }^{2}$ berupa mutasi nonsense $C 412 \rightarrow T(\mathrm{R} 138 \mathrm{X})^{3}$ dan $419 \mathrm{delG}] .{ }^{4}$ Jenis dan pola mutasi gen NPHS2 berbeda-beda oleh karena dipengaruhi perbedaan etnis dan lingkungan populasi penelitian. ${ }^{1,3,4}$ Hasil penelitian sebelumnya mendapatkan SNRS dengan mutasi gen NPHS2 menunjukkan manifestasi klinis yang lebih berat daripada SNRS tanpa mutasi gen NPHS2. Manifestasi klinis tersebut meliputi saat usia serangan pertama menjadi lebih awal, ${ }^{1,5}$ terjadinya gagal ginjal kronik lebih cepat yang dicerminkan oleh peningkatan kadar kreatinin serum, gangguan pertumbuhan, serta manifestasi lainnya karena kerusakan ginjal berupa peningkatan tekanan darah dan hematuria. ${ }^{2,6}$

Mutasi gen NPHS2 pada SNRS anak Indonesia belum diketahui, penelitian sebelumnya mengenai mutasi gen NPHS2 pada SNRS banyak mendapatkan mutasi pada ekson $3 \quad(412 C \rightarrow T$ dan 419delG) ${ }^{1-4}$ oleh karena itu dijadikan dasar untuk meneliti mutasi gen NPHS2 pada penderita SNRS anak Indonesia. Tujuan penelitian ini untuk mengetahui mutasi gen NPHS2 (412C $\rightarrow T$ dan 419delG) pada penderita SNRS anak Indonesia serta melihat manifestasi klinisnya.

\section{Metode}

Penelitian ini merupakan penelitian observasional dengan potong silang yang merupakan bagian dari disertasi, dilakukan periode September 2006Desember 2007. Sebagai subjek penderita SNRS primer yang tergolong sindrom nefrotik idiopatik dan berusia 1-14 tahun yang kontrol ke poliklinik ginjal anak di 10 rumah sakit senter pendidikan (Bandung, Jakarta, Yogyakarta, Semarang, Surabaya, Denpasar, Medan, Palembang, Makassar, dan Manado), diambil secara consecutive admission. Jumlah subjek penelitian ditentukan berdasarkan kasus SNRS yang didapat selama periode tersebut. Isolasi deoxyribonucleic acid (DNA) dan pemeriksaan mutasi genetik pada ekson $3: 412 C \rightarrow T$ dan 419delG, dilakukan di Laboratorium Unit Penelitian Kedokteran (UPK) Fakultas Kedokteran Universitas Padjadjaran Bandung.

Definisi/kriteria sindrom nefrotik idiopatik dan SNRS primer sesuai dengan kriteria International Study of Kidney Desease in Children (ISKDC), ${ }^{5}$ yaitu terdapatnya edema, proteinuria masif $(>40 \mathrm{mg} /$ $\left.\mathrm{m}^{2} / \mathrm{jam}\right)$, hipoalbuminemia $(<2,5 \mathrm{~g} / \mathrm{dL})$ dan SNRS primer merupakan sindrom nefrotik yang tidak mengalami remisi setelah pengobatan prednison 60 $\mathrm{mg} / \mathrm{m}^{2} / 24$ jam dalam empat minggu pertama.

Subjekyang memenuhi kriteriapenelitian dicatat nama, usia, jenis kelamin, kemudian dilakukan anamnesis/aloanamnesis dan pemeriksaan fisis oleh dokter spesialis konsultan ginjal anak atau dokter spesialis anak yang diketahui oleh dokter konsultan ginjal anak. Selanjutnya, orangtua/wali subjek diberikan penjelasan lisan serta tertulis sesuai dengan lembar informasi dan kemudian menandatangani lembar persetujuan kesediaan ikut dalam penelitian.

Untuk menguji perbedaan manifestasi klinis yang variabelnya berupa skala interval digunakan multivariate analysis for two independent sample ${ }^{7}$ dan untuk menguji variabel yang bentuknya nominal menggunakan rumus chi-square $\left(\mathrm{X}^{2}\right)$.

Pemeriksaan mutasi $412 \mathrm{C} \rightarrow \mathrm{T}$ dengan menggunakan metode amplification refractory mutation system-polymerase chain reaction (ARMS-PCR). ${ }^{8}$ Primer yang digunakan untuk mendeteksi mutasi di lokasi ekson 3 iniprimermutasi: 5'-3'sebagaiberikut: GGTTGTACAAGAGTAATGGAAAGAGTAAT TATATTAT, primer normal: 5'-3' GGTT GTACAA GAGTAATGGAAAGAGTAATTATATTAC, dan primer reverse: 5'-3' TGAAGAAATTGGCAAGT CAG. Sekuens DNAekson 3 yang digunakan sebagai berikut:GGTTGTACAAGAGTAATGGAAAGAG TAATTATATTACGACTGGGACATCCGCTTCC TGGAAGAGCCAAAGGCCCTGGTAAAAAAA CACTCTTTTTTTTCTAAACACCTCTCTCCTG ACTTGCCAATTTCTTCA.Campuran polymerase chain reaction $(\mathrm{PCR})$ dengan isi keseluruhan $25 \mathrm{uL}$ terdiri atas 1,5 uL DNA, primer $10 \mathrm{pg}, 2,5 \mathrm{uL} \mathrm{dNTP}$ (200 uM), 2,5 uL bufer PCR, dan 0,5 unit enzim taq polimerase. Selanjutnya dilakukan amplifikasi dengan program sebagai berikut: denaturasi dengan suhu $95{ }^{\circ} \mathrm{C}$ selama dua menit, diikuti dengan denaturasi suhu $94{ }^{\circ} \mathrm{C}$ selama 10 detik, annealing dengan suhu $54{ }^{\circ} \mathrm{C}$ selama 10 detik, dan ekstensi dengan suhu $72{ }^{\circ} \mathrm{C}$ selama 10 detik. Amplifikasi ini dilakukan sebanyak 38 siklus. Hasil PCR kemudian dielektroforesis dengan menggunakan gel agarose $2 \%$. Hasil dibaca dengan transluminator ultraviolet dan dipotret untuk dokumentasi. Produk PCR yang dihasilkan sebesar $131 \mathrm{pb}$. 
GGTTGTACAAGAGTATGAAAGAGTAATTATATTCCGACTGGGACATCCGCTTCCTGGAA GAGCCAAAGGCCCTGGTAAAAAAACACTCTTTTTTTTCTAAACACCTCTCTCCTGACTTG CCAATTTCTTCA

Pemeriksaanuntuk mendeteksimutasi419delG dilakukan dengan memakai metode restriction fragment length polymorphism-polymerase chain reaction (RFLP-PCR), ${ }^{9}$ prinsip proses analisis ini dengan menggunakan enzim endonuklease restriksi, suatu enzim yang mampu mengenal dan memotong sekuens basa DNA menjadi beberapa fragmen yang berbeda ukuran pasangan basanya. Pada proses analisis ini digunakan enzim restriksi Bfi I dari bakteri Basilus bifidus I. Sekuens basa DNA ekson 3 yang digunakan dan titik potongnya sebagai berikut: AATTTCTTCA.

Hasil pemotongan oleh enzim restriksi Bfi I (ACTGGG) pada alel normal (tanpa delesi G) menjadi dua fragmen $39 \mathrm{pb}$ dan $92 \mathrm{pb}$. Bila terjadi delesi $G$ pada alel yang tidak normal, maka enzim restriksi tersebut tidak menemukan regio restriksi, sehingga segmen DNA tersebut tidak terpotong dan hasil PCR-nya sebesar 131 $\mathrm{pb}$.

\section{Hasil}

Selama periode penelitian terkumpul 88 subjek
SNRS yang telah memenuhi kriteria inklusi. Diperlihatkan distribusi mutasi gen NPHS2 $412 C \rightarrow T$ dan 419 del $G$ pada penderita SNRS (Tabel 1).

Hasil analisis multivariat variabel interval berbagai manifestasi klinis antara kelompok SNRS dengan mutasi $412 C \rightarrow T$ atau mutasi $419 \mathrm{del} G$ dan kelompok SNRS tanpa mutasi gen tersebut tidak didapatkan perbedaan bermakna (Tabel 2).

Hasil analisis variabel nominal dari berbagai manifestasi klinis antara kelompok SNRS dengan mutasi $412 C \rightarrow T$ atau mutasi $419 \mathrm{del} G$ dan kelompok SNRS tanpa mutasi gen tersebut tidak didapatkan perbedaan, kecuali kadar kreatinin serum pada mutasi $412 C \rightarrow T$ (Tabel 3).

\section{Pembahasan}

Mutasi gen NPHS2 $412 \mathrm{C} \rightarrow T$ dan $419 \mathrm{delG}$ ditemukan $66 \%$ dan $78 \%$ pada penderita SNRS primer anak Indonesia (Tabel 1), hasil ini berbeda dengan penelitian sebelumnya pada populasi anak Eropa dan Amerika dengan SNRS yang hanya

Tabel 1 Mutasi Gen NPHS2 (412C $\rightarrow$ T dan 419delG) pada 88 Penderita Sindrom Nefrotik Resisten Steroid

\begin{tabular}{cccccc}
\hline Mutasi & $(+)$ & $\mathbf{\%}$ & $(-)$ & $\mathbf{\%}$ & Jumlah \\
\hline $412 C \rightarrow T$ & 58 & 66 & 30 & 34 & 88 \\
$419 \mathrm{del} G$ & 69 & 78 & 19 & 21 & 88 \\
\hline
\end{tabular}

Tabel 2 Manifestasi Klinis antara Kelompok SNRS dengan Mutasi 412C $\rightarrow$ T atau Mutasi 419delG dan Kelompok SNRS Tanpa Mutasi

\begin{tabular}{|c|c|c|c|c|c|c|c|c|}
\hline \multirow{3}{*}{ Variabel } & \multicolumn{4}{|c|}{ Mutasi $412 C \rightarrow T$} & \multicolumn{4}{|c|}{ Mutasi 419delG } \\
\hline & \multicolumn{2}{|c|}{$\begin{array}{c}\text { Ada } \\
(\mathrm{n}=\mathbf{5 8})\end{array}$} & \multicolumn{2}{|c|}{$\begin{array}{c}\text { Tidak Ada } \\
(\mathrm{n}=30)\end{array}$} & \multicolumn{2}{|c|}{$\begin{array}{c}\text { Ada } \\
(\mathrm{n}=69)\end{array}$} & \multicolumn{2}{|c|}{$\begin{array}{c}\text { Tidak Ada } \\
(n=19)\end{array}$} \\
\hline & $\mathbf{X}$ & SB & $\mathbf{X}$ & SB & $\mathbf{X}$ & SB & $\mathbf{X}$ & SB \\
\hline $\begin{array}{c}\text { Tekanan darah }(\mathrm{mmHg}) \\
\text { Sistol } \\
\text { Diastol }\end{array}$ & $\begin{array}{l}116,7 \\
77,7\end{array}$ & $\begin{array}{l}18,2 \\
14,4\end{array}$ & $\begin{array}{l}115,2 \\
75,3\end{array}$ & $\begin{array}{l}17,1 \\
11,9\end{array}$ & $\begin{array}{l}115,4 \\
77,0\end{array}$ & $\begin{array}{l}17,7 \\
13,2\end{array}$ & $\begin{array}{c}118,9 \\
76,6\end{array}$ & $\begin{array}{l}18,3 \\
15,1\end{array}$ \\
\hline Kreatinin serum $(\mathrm{d} / \mathrm{dL})$ & 0,93 & 0,95 & 1,03 & 1,36 & 0,97 & 1,05 & 0,93 & 1,29 \\
\hline Usia serangan pertama (bulan) & 63,3 & 44,3 & 55,2 & 43,7 & 61,8 & 44,9 & 56,0 & 41,9 \\
\hline Pertumbuhan (skor-Z) & $-1,21$ & 1,42 & $-1,21$ & 1,40 & 1,19 & 1,49 & 1,30 & 1,06 \\
\hline
\end{tabular}


Tabel 3 Manifestasi Klinis SNRS antara Kelompok dengan Mutasi Gen NPHS2 $412 C \rightarrow T$ atau 419delG dan Kelompok Penderita SNRS Tanpa Mutasi

\begin{tabular}{|c|c|c|c|c|c|c|}
\hline \multirow[b]{2}{*}{ Variabel } & \multicolumn{2}{|c|}{ Mutasi $412 C \rightarrow T$} & \multirow[b]{2}{*}{$\mathrm{p}^{*}$} & \multicolumn{2}{|c|}{ Mutasi 419delG } & \multirow[b]{2}{*}{$\mathbf{p}^{*}$} \\
\hline & $\begin{array}{c}\text { Ada } \\
(n=58)\end{array}$ & $\begin{array}{c}\text { Tidak Ada } \\
\quad(\mathrm{n}=\mathbf{3 0})\end{array}$ & & $\begin{array}{c}\text { Ada } \\
(n=69)\end{array}$ & $\begin{array}{c}\text { Tidak Ada } \\
(n=19)\end{array}$ & \\
\hline \multicolumn{7}{|l|}{$\begin{array}{l}\text { Tekanan darah } \\
\text { (mm Hg) }\end{array}$} \\
\hline $\begin{array}{l}\text { Hipertensi } \\
\text { Normal }\end{array}$ & $\begin{array}{l}34 \\
24\end{array}$ & $\begin{array}{l}14 \\
16\end{array}$ & 0,286 & $\begin{array}{l}37 \\
32\end{array}$ & $\begin{array}{c}11 \\
8\end{array}$ & 0,741 \\
\hline \multicolumn{7}{|l|}{$\begin{array}{l}\text { Kreatinin } \\
\text { serum }(\mathrm{g} / \mathrm{dL})\end{array}$} \\
\hline $\begin{array}{l}\text { Meningkat } \\
\text { Normal } \\
\text { Usia serangan }\end{array}$ & $\begin{array}{l}36 \\
22\end{array}$ & $\begin{array}{l}12 \\
18\end{array}$ & 0,049 & $\begin{array}{l}41 \\
28\end{array}$ & $\begin{array}{c}7 \\
12\end{array}$ & 0,80 \\
\hline pertama (bulan) & & & & & & \\
\hline $\begin{array}{c}0-<72 \\
>72 \\
\text { Pertumbuhan } \\
\text { (skor-Z) }\end{array}$ & $\begin{array}{l}35 \\
23\end{array}$ & $\begin{array}{c}21 \\
9\end{array}$ & 0,372 & $\begin{array}{l}42 \\
27\end{array}$ & $\begin{array}{c}14 \\
5\end{array}$ & 0,304 \\
\hline $\begin{array}{c}\text { Stunted } \\
\text { Normal } \\
\text { Hematuria }\end{array}$ & $\begin{array}{l}22 \\
36\end{array}$ & $\begin{array}{c}6 \\
24\end{array}$ & 0,087 & $\begin{array}{l}21 \\
48\end{array}$ & $\begin{array}{c}7 \\
12\end{array}$ & 0,595 \\
\hline $\begin{array}{c}\text { Ada } \\
\text { Tidak ada } \\
\end{array}$ & $\begin{array}{l}25 \\
33 \\
\end{array}$ & $\begin{array}{r}9 \\
21 \\
\end{array}$ & 0,231 & $\begin{array}{l}26 \\
43 \\
\end{array}$ & $\begin{array}{c}8 \\
11 \\
\end{array}$ & 0,726 \\
\hline
\end{tabular}

ditemukan $20-30 \%{ }^{1,3,10}$ Perbedaan hasil ini dapat diterangkan karena terdapat perbedaan dalam analisis mutasi gen NPHS2; pada penelitian ini analisis mutasi menggunakan PCR-ARMS dan FRLP, sedangkan penelitian sebelumnya menggunakan sekuensing. Analisis mutasi gen dengan sekuensing dapat mendeteksi semua jenis mutasi, sedangkan pada analisis mutasi dengan PCR-ARMS dan FRLP pada penelitian ini sudah ditentukan hanya dapat mendeteksi mutasi pada lokasi urutan pasangan basa ke-412 dan 419 dari gen NPHS2 dan banyak faktor yang mempengaruhi hasilnya. ${ }^{8}, 9$ Perbedaan lainnya, yaitupada penelitian ini subjek penelitian penderita SNRS primer, sedangkan penelitian sebelumnya penderita SNRS primer maupun sekunder. Pada SNRS primer penyebabnya kebanyakan oleh karena mutasi genetik. ${ }^{11}$ Terdapatnya perbedaan etnik dan lingkungan juga ikut berperan dalam menjelaskan mengenai perbedaan hasil penelitian. Latar belakang perbedaan etnik dan lingkungan akan menghasilkan pola mutasi yang berbeda-beda. ${ }^{3,12,13}$

Hasil analisis multivariabel dari variabel interval manifestasi klinis: nilai tekanan darah sistol dan diastol, kadar kreatinin serum, usia serangan pertama, dan pertumbuhan menunjukkan tidak ada perbedaan bermakna, baik antara kelompok SNRS dengan mutasi gen NPHS2 $412 C \rightarrow T$ ataupun mutasi 419delG dan kelompok SNRS tanpa mutasi gen-gen tersebut (Tabel 2). Begitu juga analisis perbedaan variabel dalam bentuk nominal manifestasi klinis: tekanan darah, kadar kreatinin serum, usia serangan pertama, pertumbuhan, dan hematuria antara kelompok SNRS dengan mutasi gen NPHS2 $412 C \rightarrow T$ atau mutasi $419 \mathrm{del} G$ dan kelompok SNRS tanpa mutasi gen-gen tersebut tidak ada perbedaan bermakna (Tabel 3), kecuali variabel kadar kreatinin serum yang mempunyai perbedaan bermakna $(\mathrm{p}<0,05)$ antara kelompok SNRS dengan mutasi gen NPHS2 $412 C \rightarrow T$ dan kelompok penderita SNRS tanpa mutasi gen tersebut.

Pada penelitian ini tidak terdapat perbedaan bermakna manifestasi klinis antara SNRS dengan mutasi gen NPHS2 (412C $\rightarrow T, 419 \mathrm{delG)}$ dan SNRS tanpa mutasi gen tersebut, karena pada penelitian ini analisis mutasi gen NPHS2 hanya dilakukan pada ekson 3 dengan pemeriksaan spesifik untuk mendeteksi terdapatnya mutasi $412 C \rightarrow T$ dan 419 del $G$, sedangkan mutasi lain di lokasi lainnya tidak akan ditemukan. Hal ini berbeda dengan penelitian sebelumnya dengan menggunakan sekuensing yang akan dapat mendeteksi mutasi di semua lokasi gen NPHS2. ${ }^{1-}$ ${ }^{4,6}$ Selain itu, penderita SNRS pada penelitian ini penderita SNRS primer baik kasus lama ataupun kasus baru, sehingga manifestasi klinis yang ada banyak dipengaruhi oleh faktor-faktor lainnya. Berdasarkan hasil penelitian sebelumnya, mutasi 
gen NPHS2 pada SNRS berupa mutasi titik (point mutation). ${ }^{4,14}$ Pada mutasi jenis ini terjadi perubahan hanya pada basa tunggal, dapat berupa nonsense, missense, splice site mutation, atau frameshift. Mutasi $412 C \rightarrow T$ merupakan mutasi nonsense dan mutasi 419 delG merupakan mutasi frameshift. Pada mutasi $412 C \rightarrow T$ terjadi perubahan asam amino spesifik dari suatu kodon, sehingga kodon tersebut berubah menjadi kodon terminasi yang akan menghasilkan pemendekan protein (truncated protein). Efek mutasi nonsense bergantung pada besarnya kehilangan protein. ${ }^{15}$ Pada mutasi 419delG terjadi perubahan nukleotida pada urutan basa 419 guanin mengalami delesi menjadi hilang, perubahan ini mengakibatkan terjadinya protein G140fsX180. ${ }^{7}$ Protein yang terbentuk akibat mutasi tersebut akan tertahan di retikulum endoplasma. ${ }^{16}$ Meskipun pada mutasi $412 C \rightarrow T$ terbentuk protein yang lebih pendek rantai asam aminonya dan juga pada mutasi 419delG terbentukjenis protein yang berbeda asam aminonya, tetapi protein yang terbentuk akibat kedua jenis mutasi ini belum diketahui mengenai perubahan fungsinya. Di samping itu manifestasi klinis/fenotip ekpresi gen ditentukan oleh genotip individu, lingkungan sekitar individu, serta waktu dan interaksi di antaranya, ${ }^{17}$ sehingga hal ini dapat menjelaskan terdapatnya perbedaan manifestasi klinis/fenotip dengan penelitian sebelumnya. Jackson $^{18}$ berpendapat bahwa genotip yang terekspresikan akan dipengaruhi oleh kultur dan budaya yang meliputi bahasa, kepercayaan, suku, sosialisasi, dan struktur kelas kebudayaan. Selain itu, genotip juga akan dipengaruhi oleh faktor lingkungan yang meliputi diet, pekerjaan, bentuk tubuh, toksin, kelembaban, dan ketinggian tempat tinggal. Ras juga berperan terhadap terjadinya SNRS walaupun tidak secara langsung, karena ras dan etnik dipengaruhi oleh perbedaan sosioekonomi, variasi gaya hidup, faktor kultural, dan pengaruh lingkungan sekitarnya. ${ }^{17}$ Hal ini dibuktikan dengan sangat beragamnya hasil penelitian sebelumnya mengenai jenis dan frekuensi mutasi gen NPHS2 serta manifestasi klinis pada penderita SNRS dari berbagai ras dan etnik. ${ }^{1,3,4,10,19}$

Dari penelitian ini baik mutasi $412 C \rightarrow T$ ataupun 419 delG pada penderita SNRS tidak menunjukkan perbedaan bermakna pada semua variabel manifestasi klinis yang diteliti, kecuali variabel kadar kreatinin pada mutasi $412 C \rightarrow T$.

Kadar kreatinin serum yang lebih tinggi pada kelompok SNRS dengan mutasi gen NPHS2 pada penelitian ini dapat dijelaskan secara teoritis, bahwa mutasi yang terjadi pada gen NPHS2 menyebabkan podosin yang terbentuk tidak sempurna dan terjadi pendataran foot process dengan akibat jumlah celah diafragma berkurang.
Semakin berkurang jumlah celah diafragma akan semakin berkurang permeabilitas glomerulus terhadap air dan zat kecil yang terlarut termasuk kreatinin, sehingga terdapat peningkatan kadar kreatinin serum. Gambaran kilinis lainnya akan muncul sejalan dengan bertambahnya waktu, sehingga dalam waktu 1-4 tahun sejak onset SNRS akan terjadi gagal ginjal kronik/terminal dengan manifestasi gambaran klinis yang lebih jelas. ${ }^{6}$

Mutasi 419delG merupakan mutasi frameshift, secara teoritis bila mutasinya tunggal akan memberikan manifestasi klinis yang lebih berat daripada mutasi nonsense $412 C \rightarrow T(\mathrm{R} 138 \mathrm{X})$. Pada penelitian ini tidak dapat membandingkan manifestasi klinis yang terjadi akibat mutasi $412 C \rightarrow T$ (mutasi nonsense) dengan mutasi 419delG (mutasi frameshift), karena pemeriksaannya hanya tertuju pada masing-masing lokasi tertentu, kemungkinan mutasi di lokasi lain tidak akan ditemukan dengan pemeriksaan seperti pada penelitian ini.

Simpulan, tidak terdapat perbedaan manifestasi klinis antara penderita SNRS dengan mutasi gen NPHS2 $(412 C \rightarrow T, 419$ delG $)$ dan penderita SNRS tanpa mutasi gen, kecuali kadar kreatinin serum pada penderita SNRS dengan mutasi gen $412 C \rightarrow T$.

\section{Ucapan Terima Kasih}

Penelitian ini di dukung oleh dana program RISBIN IPTEKDOK tahun 2005-2007 yang merupakan program bantuan dana dari Badan Penelitian dan Pengembangan Kesehatan DepKes RI bersama Lembaga Biologi Molekuler Eijkman sehingga penelitian ini dapat dilaksanakan.

\section{Daftar Pustaka}

1. Karle SM, Uetz B, Ronner V, Glaeser L, Hildebrandt F, Fuchshuber A. Members of the APN Study Group. Novel mutations in NPHS2 detected in both familial and sporadic steroid resistant nephrotic syndrome. J Am Soc Nephrol. 2002;13:388-93.

2. Ruf RG, Lichtenberger A, Karle SM, Haas JP, Anacleto FE, Schultheiss M, dkk. The APN study group. Patients with mutations in NPHS2/podocin do not respond to standard steroid treatment of nephrotic syndrome. J Am Soc Nephrol. 2004; 15:722-32.

3. Frieshberg Y, Rinat C, Megged O, Shapira E, Feinstein S, Rothschild AR. Mutations in NPHS2 encoding podocin are a prevalent cause of steroid resistant nephrotic syndrome among Israeli-Arab children. J Am Soc Nephrol. 2002;13:400-5.

4. Caridi G, Bertelli R, Di Duca M, Dagnin M, 
Emma F, Muda AO. Broadening the spectrum of disease related to protocin mutations. $\mathrm{J}$ Am Soc Nephrol. 2003;14:1278-86.

5. Hinkes B, Vlangos C, Heeringa S, Mucha B, Gbadegesin R, Liu J, dkk. Specific podorin mutations correlate with age of onset in streroid-resistant nephrotic syndrome. J Am Soc Nephrol. 2008;19:365-71.

6. Caridi C, Berteli R, Carrea A, Di Duca M, Catarsi P, Artero M, dkk. Prevalence, genetics, and clinical features of patients carrying podocin mutations in steroidresistant nonfamilial focal segmental glomerulosclerosis. J Am Soc Nephrol. 2001;12:2742-6.

7. Dawson B, Trapp RG. Statistical methods for multiple variables. Basic \& clinical biostatistics. Edisi ke-3. Boston: Lange Medical Books/McGraw-Hill; 2001.

8. Ye S, Dhillon S, Ke X, Collins AR, Day INM. An efficient procedure for genotyping single nucleotide polymorphisms. Nucl Acids Res. 2001;29(17):e88.

9. RFLP method-restriction fragment length polymorphism, 2001. [diunduh 5 Oktober 2008]. Tersedia dari: http://bio.davidson.edu/ courses/genomic/method/RFLP.html.

10. Caridi G, Perfumo F, Ghiggeri GM. NPHS2 (podocin) mutations in nephrotic syndrome. Clinical spectrum and fine mechanisms. Pediatr Research. 2005;57:54R-61.

11. Pollak MR. Inherited podocytopathies: FSGS and nephrotic syndrome from a genetic viewpoint. J Am Soc Nephrol. 2002;13:3016-23.

12. Maruyama K, Iijima K, Ikeda M, Kitamura
A, Tsukaguchi H, Yoshiya K, dkk. NPHS2 mutations in sporadic steroid-resistant nephrotic syndrome in Japanese children. Pediatr Nephrol. 2003;18:412-6.

13. Jackson FLC. Human genetic variation and health: new assessment approaches based on ethnogenetic layering. $\mathrm{Br}$ Med Bull. 2004;69:215-35.

14. Niaudet P. Genetic form of nephrotic syndrome. Pediatr Nephrol. 2004;19:13138.

15. Cohen RB, Bruschi M, Rinat C, Feinstein S, Zennaro C, Ghiggeri GM, dkk. Recurrent nephrotic syndrome in homozygous truncating NPHS2 mutation is not due to anti-podocinantibodies. Am J Transplant. 2007; 7:256-60.

16. Roselli S, Moutkine I, Gribouval O, Benmerah A, Antignac C. Plasma membran targeting of podocin through the classical exotic pathway: effect of NPHS2 mutations. Traffic. 2004;5:37-44.

17. Fenotipe [diunduh 8 November 2008]. Tersedia dari: http://id.wikipedia.org/wiki/ fenotipe.

18. Jackson FLC. Human genetic variation and health: new assessment approaches based on ethno genetic layering. $\mathrm{Br}$ Med Bull. 2004;69:215-35.

19. Weber S, Gribouval O, Esquivel EL, Moriniere V, Tête MJ, Legendre C, dkk. NPHS2 mutation analysis show genetic heterogeneity of steroid-resistant nephrotic syndrom and lowpost-transplant recurrence. Kidney Int. 2004;66:571-9. 